\title{
ANALISIS KEPUASAN DAN LOYALITAS KONSUMEN PRODUK TELA-TELA BAROKAH DEPAN KAMPUS BARU UNIVERSITAS HALU OLEO PADA MASA COVID-19
}

\author{
Rustiani ${ }^{1)}$, Idrus Salam ${ }^{1)}$ Muhammad Aswar Limi $^{\left.{ }^{*}\right)}$ \\ ${ }^{1}$ Department of Agribusiness Faculty of Agriculture, Universitas Halu Oleo Kendari 93232 \\ ${ }^{*}$ Corresponding author: aswar_agribusiness@yahoo.com
}

To cite this article:

Rustiani, R., Salam, I., \& Limi, M. (2021). Analisis Kepuasan dan Loyalitas Konsumen Produk Tela-Tela Barokah Depan Kampus Baru Universitas Halu Oleo pada Masa Covid-19. Jurnal Ilmiah Membangun Desa dan Pertanian, 6(5), 182 - 188. doi:http://dx.doi.org/10.37149/jimdp.v6i5.21217

Received: October 20, 2021; Accepted: December 13, 2021; Published: December 16, 2021

\begin{abstract}
This study aims to determine consumer satisfaction and loyalty of late-late products during the Covid-19 period-this research at the Barokah Tela-tela business in front of the new UHO campus using 30 respondents. Determination of respondents is done by accident (Accidental sampling), assuming that the respondent can be trusted. The variables observed in this study were consumer characteristics, tela-tela, and customer satisfaction and loyalty and satisfaction analysis methods using Customer Satisfaction Index (CSI) analysis and loyalty analysis using committed buyers, like the brand, satisfied buyers, habitual buyers, and switches. Buyers. The results show that the calculation of customer satisfaction analysis of the Customer Satisfaction Index is 0.77 or $77.46 \%$. The CSI value criterion states that the vulnerable value of $0.66-0.80$ is a satisfied consumer criterion. Based on this situation, it can be concluded that Barokah consumers have shown a satisfying attitude towards the products they consume. The survey results show that the most consumers who state that they are satisfied are the taste and cleanliness attributes of the Tela Barokah business location. The results of the calculation of consumer loyalty analysis using switcher buyer analysis are $53.33 \%$, chronic is $79.33 \%$, the satisfied buyer is $72.00 \%$, liking the brand is $76.67 \%$, and committed buyer is $62.00 \%$. The analysis results are mainly in the index interval of $61.00-80.00$, which means that Barokah consumers have shown a loyal attitude. The existence of the Covid-19 pandemic did not hurt the decline in consumer demand for snack products in the business. This is known from the income that remains in the range of \pm IDR400.000 - IDR1.500.000 - every day both before and during the Covid-19 outbreak in Kendari City.
\end{abstract}

Keywords: consumers; covid 19; loyalty; satisfaction; tela-tela; Universitas Halu Oleo

\section{PENDAHULUAN}

Singkong (Manihot utilissima) merupakan tanaman perdu tahunan Euphorbiaceae yang tumbuh di daerah beriklim tropis dan subtropis. Ubi kayu telah lama dikenal dan dibudidayakan oleh sebagian besar penduduk pedesaan maupun di wilayah pinggiran kota di seluruh Indonesia, namun membutuhkan komponen pendukung yang ada disetiap tempat, seperti lahan, sarana dan prasarana, serta industri pengolahan, permintaan pasar, dan lain sebagainya.

Seiring dengan berkembangnya kebutuhan masyarakat akan pemenuhannya, demikian pula keragaman kebutuhan manusia, khususnya di bidang pangan. Dari segi budaya, geografi, dan rutinitas sehari-hari, setiap daerah memiliki ciri khasnya masing-masing. Padi, jagung, ubi kayu, dan ubi jalar merupakan empat tanaman pangan utama yang dihasilkan di Kota Kendari (BPS, 2020). Hasil singkong berada di urutan kedua setelah beras di Kota Kendari, disusul oleh jagung dan ubi jalar. Singkong dapat diolah menjadi berbagai macam barang olahan (Darmawan et al., 2013). Pertumbuhan agroindustri singkong dimaksudkan untuk meningkatkan peluang kerja dan pendapatan masyarakat dan petani. Singkong adalah tanaman komersial, sebagian besar digunakan untuk menopang usaha kecil berbasis singkong.

Agroindustri adalah usaha yang mengubah sumber daya mentah pertanian menjadi komoditas bernilai tambah yang dapat dikonsumsi oleh masyarakat luas. Bahan agroindustri, berbeda 
dengan industri lain, tersedia secara luas di daerah setempat; Dengan kata lain, bahan baku agroindustri tidak bergantung pada impor dari negara lain. Singkong dapat dibuat menjadi berbagai olahan makanan, seperti singkong rebus, singkong goreng, singkong bakar, tape, kolak, gethuk, dan keripik singkong (Harsita \& Amam, 2019).

Singkong diolah menjadi makanan ringan oleh banyak orang di Kota Kendari. Akibatnya, wilayah ini dikenal di seluruh Sulawesi Tenggara sebagai pusat produksi singkong olahan. Untuk produksi singkong yang relatif besar di Kota Kendari, peran pemerintah dan masyarakat dalam pertumbuhan agroindustri sangat penting. Pengolahan singkong menjadi jajanan merupakan sektor yang sedang berkembang di Kota Kendari, khususnya di Desa Lalolara, Kecamatan Kambu (depan Kampus Baru UHO). Industri makanan ringan benar-benar merupakan usaha sepanjang tahun. Di zaman sekarang ini, ada semakin banyak makanan ringan siap saji yang tersedia dalam berbagai selera.

Dunia usaha semakin dinamis, seiring dengan meningkatnya keinginan masyarakat akan produk dan jasa yang sesuai dengan segala keinginannya. Epidemi Covid-19, di sisi lain, tidak terbantahkan dalam pengaruhnya terhadap kelangsungan hidup jangka panjang usaha Mikro, Kecil, dan Menengah (UMKM). Covid-19 tampaknya telah berdampak pada perilaku masyarakat dalam prilaku ekonomi dan bisnis, selain memiliki konsekuensi medis yang buruk. Para pelaku usaha, khususnya yang bergerak di sektor industri massal, mulai merumahkan personelnya (Yusup et al., 2020). Berdasarkan survei, 96 persen pelaku usaha (termasuk 1.785 koperasi dan 163.713 usaha mikro, kecil, dan menengah) menyatakan bahwa Covid-19 berdampak negatif terhadap proses bisnis mereka (Soetjipto, 2020).

Sebuah perusahaan harus memberikan kebahagiaan kepada pelanggan untuk menjamin kelangsungan usaha dalam menghadapi pandemi dan persaingan yang ketat (Prasetio, 2012). Perilaku konsumen dalam konsumsi makanan dan minuman juga telah berubah sebagai akibat dari keterbatasan sosial skala besar. Para pelaku di dunia bisnis harus memikirkan praktik ini. Persyaratan tersebut harus dipenuhi melalui layanan yang membuat pemesanan makanan dan minuman menjadi lebih mudah dan memuaskan bagi pelanggan (Prakoso, 2020). Keinginan membeli kembali produk dipengaruhi oleh kepuasan pelanggan. Jika kualitas produk dan layanan ditingkatkan, minat beli pelanggan akan tumbuh. Niat membeli digambarkan sebagai perilaku konsumen yang menunjukkan betapa seriusnya dia dalam melakukan pembelian.

Usaha tela-tela adalah bisnis yang sangat aman untuk dimulai karena dapat menghasilkan antara Rp. 400.000 dan Rp. 1.500 .000 setiap hari. Konsumen dapat dengan mudah menjangkau usaha ini karena memiliki lokasi permanen. Lokasinya sangat menguntungkan karena dekat dengan kampus Universitas Halu Oleo (UHO). Pendekatan distribusi perusahaan didasarkan pada penjualan langsung ke konsumen.

Untuk menghindari virus corona di masa epidemik saat ini, pelanggan sering kali lebih memilih tempat dengan kebersihan yang memadai. Oleh karena itu, layanan terkait Covid-19 harus terus ditingkatkan untuk menjaga kepuasan dan loyalitas pelanggan. Selain itu, kualitas sangat penting agar produk dapat dikenali dan dipercaya oleh masyarakat umum. Menurut Fasyni et al. (2019), kepuasan adalah faktor dalam menciptakan loyalitas. Namun, kepuasan pelanggan bukanlah aspek terpenting dalam mempertahankan pelanggan. Banyaknya permintaan berbanding lurus dengan tingkat kepuasan pelanggan terhadap suatu produk. Menurut Gadung et al. (2015), label halal, rasa, harga, aroma, dan tanggal kedaluwarsa adalah lima faktor terpenting dalam menentukan kepuasan. Perusahaan harus terus meningkatkan kualitas barangnya dan memberikan informasi berupa promosi baik di media cetak maupun elektronik agar konsumen tidak salah dalam melakukan pembelian suatu produk. Promosi penjualan, menurut Rahmayanti and Ekawati (2021), memiliki pengaruh yang baik dan substansial terhadap loyalitas klien. Hal ini menunjukkan bahwa semakin kuat promosi penjualan pelanggan, semakin tinggi loyalitas pelanggan. Merek produk menurut Dzulfikar et al. (2021), adalah atribut yang dihargai pelanggan tetapi perusahaan belum mampu memberikan hasil yang lebih baik. Perusahaan harus merancang taktik untuk meningkatkan citra produk mereka. Kegiatan promosi dan periklanan yang lebih intens adalah salah satu solusi yang layak. Penguatan citra merek, menurut $\mathrm{Wu}$ and Chen (2019), mendorong pengenalan merek pelanggan. Ketika produk perusahaan memiliki citra merek yang positif, orang menunjukkan lebih banyak identifikasi merek untuk produk tersebut.

Kepuasan dan loyalitas konsumen terhadap konsumsi produk memiliki keberagaman kepuasan. Di masa pandemik Covid-19 konsumen lebih berhati-hati dalam membeli suatu produk dan lebih mengutamakan kebutuhan pokok sebagai penunjang kehidupan dibanding mengkonsumsi makanan pemuas seperti makanan ringan. Tujuan penelitian adalah untuk mengetahui tingkat kepuasan dalam menjaga konsumen agar tetap loyal terhadap produk makanan ringan tela-tela Barokah pada masa Covid-19. 


\section{MATERI DAN METODE}

Pada bulan September 2021 penelitian ini dilaksanakan di Kota Kendari tepatnya di usaha Barokah depan kampus baru Universitas Halu Oleo, diawali dengan perancangan rencana penelitian, pengumpulan dan pengolahan data, dan diakhiri dengan perumusan kesimpulan dari hasil penelitian. Partisipan dalam penelitian ini adalah seluruh pelanggan usaha tela-tela Barokah yang melakukan pembelian produk tela-tela. Responden dipilih secara kebetulan (accidental sampling) dengan asumsi bahwa responden dapat dipercaya. Data primer diperoleh dari responden usaha tela-tela Barokah dengan teknik wawancara langsung atau penyebaran kuesioner dengan berbagai pertanyaan yang berkaitan dengan data yang dicari dalam penelitian. Data sekunder dari perusahaan, seperti statistik penjualan dan deskripsi perusahaan dan struktur organisasinya, serta data dari lembaga terkait seperti Biro Pusat Statistik dan Kantor Camat.

Pendekatan Customer Satisfaction Index (CSI) dapat digunakan untuk menentukan kepuasan pelanggan. Menurut Ayuni et al. (2017), penetapan Mean Importance Score dan Mean Satisfaction Score (MSS) yang dihasilkan dari rata-rata tingkat kepentingan dan kinerja masing-masing karakteristik dapat digunakan untuk menentukan besaran CSI. Persamaan berikut dapat digunakan untuk menghitung nilai MIS dan MSS, masing-masing:

$$
\begin{aligned}
\text { MIS } & =\frac{\sum \mathrm{Yi}}{\mathrm{n}} \\
\mathrm{MSS} & =\frac{\sum \mathrm{xi}}{\mathrm{n}}
\end{aligned}
$$

Dimana, MIS = Mean Importance Score, MSS = Mean Satisfaction Score, $\mathrm{n}=$ jumlah responden, $\mathrm{Yi}=$ nilai kepentingan atribut ke-I, $\mathrm{xi}=$ nilai kinerja atribut ke-i

Menghitung Mean Importance Score atau nilai rata-rata tingkat kepentingan (MISi) setiap atribut yang dilaporkan sebagai persentase dari Mean Importance Score (MISi) keseluruhan untuk semua atribut yang dievaluasi menggunakan fungsi Weighted Factor (WF). Persamaan berikut dapat digunakan untuk menghitung nilai WF:

$$
\mathrm{WF}_{\mathrm{i}}=\frac{\mathrm{MIS}_{\mathrm{i}}}{\sum \mathrm{MIS}_{\mathrm{i}}}
$$

Dimana, WF = Weighted Factor ke-i, MISi = Mean Importance Score ke-i

Menghitung Weight Score (WS) atau skor tertimbang. Bobot ini merupakan perkalian antara WF dengan rata-rata tingkat kepuasan.

$$
W S_{i}=W_{i} \times M S S_{i}
$$

Dimana, $\mathrm{WSi}=$ Weight Score ke-I, WFi $=$ Weighted Factor ke-I, MSSi $=$ Mean Satisfaction Score ke-i

Menghitung Weighted Average Total (WAT), fungsi dari total Weighted Score (WS) atribut ke1 (a1) hingga atribut ke-n (an)

$$
\mathrm{WAT}=\mathrm{WSa} 1+\mathrm{WSa} 2+\ldots+\mathrm{WSan}
$$

Dimana, WAT $=$ Weighted Average Total, WSa $=$ Weighted Score

Menentukan Customer Satisfaction Index (CSI).

$$
\mathrm{CSI}=\frac{\mathrm{WA}}{\mathrm{HS}} \mathrm{X} 100 \%
$$

Dimana, $\mathrm{CSI}=$ Customer Satisfaction Index, WA $=$ Weighted Average, $\mathrm{HS}=$ Highest Scale (skala maksimum) 
Tabel 1. Kriteria Nilai Customer Satisfaction Index (CSI)

\begin{tabular}{cc}
\hline Nilai CSI & Kriteria CSI \\
\hline $0,81-1,00$ & Sangat puas \\
$0,66-0,80$ & Puas \\
$0,51-0,65$ & Cukup Puas \\
$0,35-0,50$ & Kurang Puas \\
$0,00-0,34$ & Tidak Puas \\
\hline
\end{tabular}

Sumber: Leliana and Oktaviastuti (2020)

Pemeriksaan pelanggan yang beralih, pembeli yang sering, pembeli yang senang, menikmati merek, dan konsumen yang berkomitmen digunakan untuk menilai loyalitas. Menurut Manuaba (2015), rumus berikut dapat digunakan untuk menghitung proporsi konsumen setia pada setiap tingkat studi pembeli beralih, pembeli kebiasaan, pembeli senang, mencintai merek, dan pembeli berkomitmen:

$$
\% \mathrm{~F}=\mathrm{Fi} / \Sigma \mathrm{Fi} \times 100 \%
$$

Dimana, $\% \mathrm{~F}=$ Persentase frekuensi, $\mathrm{Fi}=$ Jumlah jawaban dalam setiap bobot, $\Sigma \mathrm{Fi}=$ Total jumlah jawaban

Menghitung nilai indeks:

$$
\% \mathrm{I}=(\% \mathrm{~F} 1 \times 1)+(\% \mathrm{~F} 2 \times 2)+(\% \mathrm{~F} 3 \times 3)+(\% \mathrm{~F} 4 \times 4)+(\% \mathrm{~F} 5 \times 5) / 5
$$

Dimana, $\% \mathrm{l}=$ Persentase indeks, $\mathrm{F} 1=$ Frekuensi responden yang menjawab $1, \mathrm{~F} 2=$ Frekuensi responden yang menjawab $2, \mathrm{~F} 3=$ Frekuensi responden yang menjawab $3, \mathrm{~F} 4=$ Frekuensi responden yang menjawab 4, F5 = Frekuensi responden yang menjawab 5 dari skor yang akan digunakan dalam daftar pertanyaan.

Tabel 2. Interpretasi nilai index

\begin{tabular}{cc}
\hline Interval Nilai Indeks & Kriteria \\
\hline $00,00-20,00$ & Sangat Tidak Loyal \\
$21,00-40,00$ & Tidak Loyal \\
$41,00-60,00$ & Kurang Loyal \\
$61,00-80,00$ & Loyal \\
$81,00-100,00$ & Sangat Loyal \\
\hline
\end{tabular}

Sumber: Manuaba (2015)

\section{HASIL DAN PEMBAHASAN}

\section{Analisis Customer Satisfaction Index}

Persepsi pengguna terhadap kinerja (kinerja) produk/jasa dalam memenuhi harapan pelanggan/pengguna menentukan kepuasan pelanggan (customer satisfaction) (Sinnun, 2017).

Tabel 3. Rekapitulasi Nilai MIS, MSS, WF dan WS

\begin{tabular}{ccccc}
\hline No. & Nilai MIS & Nilai MSS & Nilai WF & WS \\
\hline 1. & 4,63 & 3,93 & 0,07 & 0,27 \\
2. & 4,27 & 3,24 & 0,06 & 0,21 \\
3. & 4,67 & 3,48 & 0,07 & 0,24 \\
4. & 4,60 & 3,73 & 0,07 & 0,26 \\
5. & 4,27 & 3,53 & 0,06 & 0,23 \\
6. & 4,57 & 4,23 & 0,07 & 0,29 \\
7. & 4,03 & 3,67 & 0,06 & 0,22 \\
8. & 4,70 & 4,07 & 0,07 & 0,29 \\
9. & 4,60 & 4,00 & 0,07 & 0,28 \\
10. & 4,33 & 3,83 & 0,07 & 0,25 \\
11. & 4,33 & 4,03 & 0,07 & 0,26 \\
12. & 4,40 & 4,17 & 0,07 & 0,28 \\
13. & 4,60 & 4,03 & 0,07 & 0,28 \\
14. & 4,03 & 4,17 & 0,06 & 0,25 \\
\hline
\end{tabular}


Tabel 3. Rekapitulasi Nilai MIS, MSS, WF dan WS

\begin{tabular}{ccccc}
\hline No. & Nilai MIS & Nilai MSS & Nilai WF & WS \\
\hline 15. & 4,60 & 3,93 & 0,07 & 0,27 \\
\hline & 66,63 & 58,06 & & WA $=3,87$ \\
\hline
\end{tabular}

Berdasarkan perhitungan, data menunjukan bahwa total rata-rata nilai Mean Importance Score adalah 66,63 dan Mean Satisfaction Score (MSS) adalah 58,06. Hasil ini diperoleh dari ratarata nilai kepentingan dan kinerja usaha tela-tela Barokah. Total kepentingan dari usaha tela-tela Barokah berdasarkan hasil wawancara 30 responden adalah 1.999 sedangkan tingkat kinerja sebanyak 1.731 yang didapatkan dari penjumlahan keseluruhan skor peringkat yang diberikan responden baik kinerja maupun kepentingan dari suatu atribut yang ditawarkan.

Tahap kedua adalah menghitung Weight Factors (WF). Bobot ini merupakan persentase nilai MIS per atribut terhadap total MIS seluruh atribut. Berdasarkan data diatas, perhitungan Weight Factors (WF) pada atribut pertama didapatkan nilai sebesar $7,0 \%$ yang berasal dari nilai Mean Importance Score atribut tersebut sebesar 4,63 dikali dengan angka 100\% dan kemudian dibagi dengan total Mean Importance Score yaitu sebesar 66,63. Perhitungan ini berlaku untuk setiap atribut dalam mencari nilai WF masing-masing.

Skor bobot (WS) dihitung dengan mengalikan faktor bobot (WF) dengan tingkat kepuasan rata-rata Mean Satisfaction Score (MSS). Hasil perhitungan untuk menetapkan nilai Weight Score (WS) pada atribut pertama dilakukan pada langkah ini dengan mengalikan WF (7,0 persen) dengan Mean Satisfaction Score $(3,93)$, sehingga diperoleh total WS sebesar 3,87 .

\section{Customer Satisfaction Index}

Skor tertimbang dibagi dengan skala maksimum yang digunakan untuk menentukan nilai persentase CSI. Berdasarkan perhitungan akhir, dapat diketahui nilai Customer Satisfaction Index diperoleh sebesar 0,77 atau $77,46 \%$. Kriteria nilai CSI menyatakan bahwa rentan nilai 0,66-0,80 merupakan kriteria konsumen yang puas. Berdasarkan keadaan ini dapat disimpulkan bahwa pengunjung usaha tela-tela Barokah yang mengonsumsi tela-tela menunjukan sikap yang puas terhadap produk yang dikonsumsinya. Hasil survei menunjukan paling banyak konsumen yang menyatakan sangat puas dan puas adalah terhadap atribut rasa dan kebersihan lokasi usaha. Konsumen tela-tela Barokah sebagian besar menunjukan sikap pentingnya atribut kebersihan terhadapat tingkat kepuasan. Hal ini justru berbanding terbalik dengan hasil penelitian Yola and Budianto (2013) yang menyatakan bahwa kebersihan dianggap tidak begitu penting oleh konsumen dan tidak berpengaruh terhadap kepuasan. Konsumen akan melakukan penilaian pasca pembelian terhadap konsumsi yang telah mereka lakukan. Produk dan layanan mungkin puas atau tidak puas sebagai konsekuensi dari evaluasi (Djamaludin et al., 2009).

Perilaku pembelian seseorang juga dipengaruhi oleh ciri-ciri kepribadian pelanggan yang bersangkutan. Meskipun kepribadian adalah salah satu ide yang berguna dalam meneliti perilaku pelanggan, beberapa pemasar merasa bahwa kepribadian memengaruhi jenis dan merek barang yang dibeli (Rumondang et al., 2020). Kebahagiaan atau ketidakpuasan konsumen terhadap produk, jasa, atau ide yang dikonsumsi diwakili oleh sikap. Sumber daya konsumen, motivasi dan keterlibatan, pengetahuan, sikap, kepribadian, gaya hidup, dan demografi adalah lima metode penting untuk mempengaruhi perilaku konsumen (Firmansyah \& Haryanto, 2019).

\section{Analisis Loyalitas}

Pelanggan setia adalah seseorang yang menggunakan atau mengkonsumsi barang atau jasa dari perusahaan atau merek yang sama secara teratur atau berulang. Besarnya loyalitas pelanggan usaha tela-tela Barokah ditentukan dengan menganalisis konsumen yang beralih, pembeli yang sering membeli, pembeli yang senang menikmati merek, dan pembeli yang berkomitmen.

Tabel 4. Persentase analisis loyalitas

\begin{tabular}{cccc}
\hline No. & \multicolumn{1}{c}{ Analisis Loyalitas } & Persentase & Kriteria \\
\hline 1. & Switcher Buyer & $53,33 \%$ & Kurang loyal \\
\hline 2. & Habitual Buyer & $79,33 \%$ & loyal \\
\hline 3. & Satisfied Buyer & $72,00 \%$ & Loyal \\
\hline 4. & Liking the Brand & $76,67 \%$ & Loyal \\
\hline 5. & Committed Buyer & $62,00 \%$ & loyal \\
\hline
\end{tabular}


Hasil perhitungan analisis loyalitas konsumen menggunakan analisis switcher buyer diperoleh hasil 53,33\%. Pada tingkat ini konsumen dikatakan kurang loyal. Kurang loyalnya konsumen pada analisis ini dikarenakan seluruh penjual tela-tela yang berada di sekitar kampus baru UHO mematok harga yang sama sehingga masalah harga tidak menjadi hal yang terlalu diperhatikan oleh konsumen. Habitual buyer sebesar $79,33 \%$, satisfied buyer sebesar $72,00 \%$, liking the brand sebesar $76,67 \%$, dan committed buyer $62,00 \%$. Hasil analisis tersebut sebagian besar berada pada interval indeks $61,00-80,00$ sehingga dapat disimpulkan bawa konsumen tela-tela Barokah menunjukan sikap yang loyal. Adanya pandemik Covid-19 tidak memberi dampak negatif terhadap penurunan permintaan konsumen terhadap produk makanan ringan tela-tela pada usaha tela-tela Barokah. Hal ini diketahui dari jumlah pemasukan yang tetap berada di kisaran $\pm R p 400.000$ - Rp1.500.000,- setiap harinya baik sebelum maupun selama berlangsungnya Covid-19 di Kota Kendari. Listyawati (2013) mengatakan bahwa Loyalitas pelanggan dikembangkan dari waktu ke waktu melalui proses pembelajaran dan berdasarkan hasil pengalaman pelanggan melalui pembelian berulang. Satusatunya cara untuk menghasilkan klien yang loyal adalah dengan memberi mereka tingkat kepuasan yang tinggi. Kepuasan konsumen dapat didefinisikan sebagai perbedaan antara apa yang diharapkan pelanggan (biasanya disebut sebagai nilai yang diantisipasi) dan apa yang ingin diwujudkan perusahaan untuk memenuhi harapan pelanggan (sering disebut sebagai nilai yang dirasakan) (Harminingtayas, 2012). Hal ini didukung oleh pernyataan Sarastila et al. (2021) bahwa persepsi kegunaan, kemudahan penggunaan, kepercayaan, dan risiko dapat mempengaruhi minat beli.

\section{KESIMPULAN}

Customer Satisfaction Index diperoleh sebesar 0,77 atau $77,46 \%$. Kriteria nilai CSI menyatakan bahwa rentan nilai 0,66-0,80 merupakan kriteria konsumen yang puas, baik terhadap kualitas produk maupun kualitas pelayaan pada usaha tela-tela Barokah. Atribut rasa dan kebersihan lokasi usaha tela-tela Barokah memiliki tingkat kepentingan dan kinerja yang memuaskan sehingga perlu dipertahankan. Analisis loyalitas konsumen menggunakan analisis switcher buyer diperoleh hasil 53,33\%, habitual buyer sebesar 79,33\%, satisfied buyer sebesar $72,00 \%$, liking the brand sebesar $76,67 \%$, dan committed buyer $62,00 \%$ yang sebagian besar menunjukan angka persentase indeks yang loyal. Tidak adanya fluktuasi penurunan jumlah permintaan produk tela-tela Barokah sehingga jumlah permintaan tidak terpengaruh oleh adanya pandemik Covid-19.

\section{REFERENSI}

Ayuni, N. W. D., Adiaksa, I. M. A., \& Sari, I. G. A. M. K. K. (2017). Analisis Kepuasan Pelanggan Terhadap Produk Kopi Biji Salak. Jurnal Bisnis dan Kewirausahaan, 13(2), 120.

BPS. (2020). Produksi Tanaman Pangan di Kota Kendari dalam Satuan Ton, 2015-2018

Darmawan, M. R., Andreas, P., Jos, B., \& Sumardiono, S. (2013). Modifikasi Ubi Kayu dengan Proses Fermentasi Menggunakan Starter Lactobacillus Casei untuk Produk Pangan. Jurnal Teknologi Kimia dan Industri, 2(4), 137-145.

Djamaludin, M. D., Sumarwan, U., \& Mahardikawati, G. N. A. (2009). Analisis Kepuasan dan Loyalitas Konsumen Jamu Gendong di Kota Sukabumi. Jurnal IImu Keluarga dan Konsumen, 2(2).

Dzulfikar, A., Jahroh, S., \& Ali, M. M. (2021). Strategi Peningkatan Kepuasan Konsumen Jahe Sang Jawara di Masa Pandemi Covid-19 dengan Pendekatan Importance Performance Analysis. Jurnal Aplikasi Bisnis dan Manajemen, 7(3), 681-681.

Fasyni, A., Najib, M., \& Kirbrandoko. (2019). Kepuasan dan Loyalitas Konsumen Air Minum Isi Ulang di Kota Padang. Jurnal Praktik Bisnis, 8(1), 37.

Ferinia, R., Tanjung, R., Purba, B., Lestari, N., Mastuti, R., Utami, N. R., Dewi, I. K. (2021). Perilaku Konsumen Kepariwisataan. Yayasan Kita Menulis.

Firmansyah, F., \& Haryanto, R. (2019). Manajemen Kualitas Jasa (Peningkatan Kepuasa dan Loyalitas). Duta Media.

Gadung, A., Zakaria, W. A., \& Murniati, K. (2015). Analisis Kepuasan dan Loyalitas Konsumen Kopi Bubuk Sinar Baru Cap Bola Dunia (SB-CBD) di Kota Bandar Lampung. jurnal ilmu-ilmu agribisnis, 3(4).

Harminingtayas, R. (2012). Analisis Faktor Pelayanan, Fasilitas, Promosi dan Lokasi terhadap Kepuasan Penghuni Perumahan Permata Puri Ngalian Semarang. Jurnal Stie Semarang, $4(3)$.

Harsita, P. A., \& Amam. (2019). Analisis Sikap Konsumen terhadap Atribut Produk Olahan Singkong. Jurnal Sosial Ekonomi Pertanian, 3(1), 19-27. 
Leliana, A., \& Oktaviastuti, B. (2020). Analisis Kepuasan Penumpang Kereta Api terhadap Angkutan Umum di Stasiun Madiun. Jurnal Teknik Sipil, 5(1), 1-6.

Listyawati, I. H. (2013). Implementasi Relationship Marketing Sebagai Strategi Mempertahankan Loyalitas Pelanggan. Jurnal Bisnis, Manajemen, dan Akuntansi, 1(2).

Manuaba, I. B. G. B. (2015). Analisis Tingkat Brand Loyalty Konsumen Sepada Motor Merek Honda di PT. Tri Mitra Bali Motor Semabaung Gianyar. Jurnal Pendidikan Ekonomi Undiksha, 5(1).

Prakoso, F. A. (2020). Dampak Corona Virus Disease (Covid-19) terhadap Industri Food and Beverages. Jurnal Manajemen Bisnis, 33(2), 1-4.

Prasetio, A. (2012). Pengaruh Kualitas Pelayanan dan Harga terhadap Kepuasan Pelanggan. Jurnal Manajemen Analisis, 1(4).

Rahmayanti, P. L. D., \& Ekawati, N. W. (2021). Pengaruh Kualitas Layanan dan Promosi Penjualan terhadap Kepuasan dan Loyalitas Pelanggan Menggunakan Online Food Delivery Service di Bali. Jurnal Manajemen dan Bisnis Equilibrium, 7(2), 146-161.

Rumondang, A., Sudirman, A., Sitorus, S., Kusuma, A. H. P., Manuhutu, M., Sudarso, A., . . Arif, N. F. (2020). Pemasaran Digital dan Perilaku Konsumen. Yayasan Kita menulis.

Sarastila, C., Pertiwi, V. i. A., \& Kustanti, A. (2021). Model Penerimaan Teknologi dan Kepercayaan Konsumen terhadap Minat Beli Tanaman Hias Melalui E-Commerce Saat Pandemi Covid-19. Jurnal Sosial Ekonomi Pertanian, 17(2), 13-26.

Sinnun, A. (2017). Analisis Kepuasan Pengguna LMS Berbasis Web dengan Metode Servqual, IPA dan CSI. Jurnal Informatika, 4(1).

Soetjipto, H. N. (2020). Ketahanan UMKM Jawa Timur Melintasi Pandemi COVID-19. K-Media.

Wu, C. S., \& Chen, T.-T. (2019). Building Brand's Value: Research on Brand Image, Personality, and Identification. International Journal of Management, Economics and Social Sciences, 8(4), 299-318.

Yola, M., \& Budianto, D. (2013). Analisi Kepuasan Konsumen terhadap Kualitas Pelayanan dan Harga Produk pada Supermarket dengan Menggunakan Metode Importance Performance Analysis (IPA). Jurnal Optimasi Sistem Industri, 12(12).

Yusup, D. K., Badriyah, M., Suyandi, D., \& Asih, V. S. (2020). Pengaruh Bencana Covid-19, Pembatasan Sosial, dan Sistem Pemasaran Online terhadap Perubahan Perilaku Konsumen dalam Membeli Produk Retail. 1(1). 